\title{
Factors Related to Behavior of Using Personal Protective Equipment on Filling Lithos Workers
}

\author{
Faktor yang Berhubungan dengan Perilaku Penggunaan Alat Pelindung Diri \\ Pekerja Filling Lithos
}

\author{
Siregar Reymond Sahala Pangihutan \\ PT Multi Nabati Sulawesi (Wilmar Industry Group) \\ Jalan. Raya Madidir, Puceda, Madidir, Bitung City, North Sulawesi 95541, Indonesia
}

\begin{abstract}
Introduction: Every workplace has risks and risks to the safety and health of workers. Personal Protective Equipment (PPE) as the last control or last effort to control risk in workplace. Using personal protective equipment is influenced by a person's behavior which consists of three factors namely predisposing factors, enabling factors and driving factors. The purpose of this study was to analyze factors related to the behavior of using PPE on workers in the filling lithos process PT. Pertamina Lubricants Production Unit Gresik. Methods: This study was an observational analytic study, using a cross sectional research design. The research sample was 41 people, taken randomly using simple random sampling. Data collection includes age, education, years of service, knowledge, motivational attitudes of PPE availability, supervision and regulations regarding PPE. The data analysis used in this study is Spearman's correlation. Results: Showed that there was a relationship between age factors $(p=0.004)$ and the behavior of PPE use while other factors were knowledge $(p=$ $0.338)$, motivation $(p=0.137)$, availability of PPE, regulations on PPE $(p=0.624)$ with no association behavior of using PPE. Most samples behave disobediently using PPE. Conclusion: Age has a relationship with my personal use of personal protective equipment and most of the workers behave disobedient using personal protective equipment.
\end{abstract}

Keywords: behavior, filling lithos workers, personal protective equipment

\section{ABSTRAK}

Pendahuluan: Setiap tempat kerja memiliki bahaya dan risiko terhadap keselamatan dan kesehatan pekerja. Alat pelindung diri (APD) merupakan upaya atau saha terakhir untuk mengendalikan risiko di tempat kerja. Penggunaan alat pelindung diri dipengaruhi oleh perilaku seseorang yang terdiri dari tiga faktor yaitu faktor predisposisi, faktor pemungkin dan faktor pendorong. Tujuan dari penelitian ini adalah menganalisis faktor yang berhubungan dengan perilaku penggunaan APD pada pekerja di proses filling lithos PT. Pertamina Lubricants Production Unit Gresik. Metode: Penelitian ini merupakan penelitian observasional analitik, menggunakan desain penelitian cross sectional. Sampel penelitian sebesar 41 orang, diambil secara acak menggunakan simple random sampling. Pengumpulan data meliputi umur, pendidikan, masa kerja, pengetahuan, sikap motivasi ketersediaan APD, pengawasan dan peraturan tentang APD. Analisis data yang digunakan dalam penelitian ini adalah korelasi Spearman. Hasil: Penelitian menunjukkan terdapat hubungan antara faktor umur $(p=0,004)$ dengan perilaku penggunaan APD sedangkan faktor yang lainnya pengetahuan ( $p=0,338)$, motivasi $(p=0,137)$, ketersediaan $A P D$, peraturan tentang $A P D(p=0,624)$ tidak ada hubungan dengan perilaku penggunaan APD. Sebagian besar sampel berperilaku tidak patuh menggunaan APD. Simpulan: Umur/ usia yang memiliki hubungan dengan perialaku penggunaan alat pelindung diri dan sebagaian besar pekerja berperilaku tidak patuh menggunakan alat pelindung diri.

Kata kunci: alat pelindung diri, pekerja filling lithos, perilaku

Author for Correspondence:

Siregar Reymond Sahala Pangihutan

E-mail: reymondsiregar1@gmail.com

Telephone: +6285340178809

(C)2019 IJOSH. Open access under CC BY NC-SA license doi: 10.20473/ijosh.v8i3.2019.302-309. Received December 11, 2018, received in revised form January 18, 2019, Accepted December 12, 2019, Published: December 2019 


\section{INTRODUCTION}

Work accidents that occur in Indonesia tend to increase along with the more advanced and developing industries. According to data from Social Insurance Administration Organization for Employment that work accident cases nationwide in 2017 increased compared to 2016. Data on the number of occupational accident cases in Indonesia was ordered by BPJS Employment in 2016, there were 101.364 cases of workplace accidents and in 2017 recorded 123.000 cases of workplace accidents occur. Work accident cases in 2016 to 2017 in Indonesia increased to 123.000 . This indicates that every day 337 cases of workplace accidents occur in Indonesia.

According to the International Labour Organization (2017) that as many as 860.000 workers experience workplace accidents and diseases worldwide every year, and as many as 6.400 workers die every day due to work-related accidents and diseases. The high number of occupational accidents and work-related diseases is caused by several causes, namely not optimal supervision and application of occupational safety and health (K3), the low awareness and behavior of occupational safety and health (K3) in the workplace and the ineffective control of potential hazards that cause the amount of risk of work-related illnesses and workplace accidents in the company.

According to Ramli (2010) related to the magnitude of the risk of workplace accidents that may occur, a company must seek risk control by implementing a hierarchy of controls namely elimination, substitution, engineering, administrative and personal protective equipment (PPE). The potential hazards and risks that have not been fully or not yet effectively can be controlled, so that the last risk control efforts are carried out to minimize or reduce the severity of occupational illnesses or workplace accidents by using personal protective equipment (PPE).

The use of personal protective equipment (PPE) in the implementation there are still many workers who behave not using personal protective equipment (PPE). Many factors influence workers not to use personal protective equipment (PPE), it is related to behavior. According to Notoatmodjo (2014) states that human behavior is formed or influenced by three factors, namely predisposing factors manifested in knowledge, attitudes, beliefs, beliefs, values, motivations and elements contained in the individual include age, experience, education. Enabling factors are manifested in the physical environment, available or unavailability of facilities or facilities, and reinforcing factors are manifested in the influence of people or reference groups from the adopted behavior. These three factors determine, support and strengthen the formation of human behavior, especially the behavior of workers using personal protective equipment (PPE).

The results of Saputro (2015) showed that from 40 study samples there were 23 respondents $(57.5 \%)$ who did not use PPE in full. The results of the Fransiska study (2014) show that from 110 respondents, 57 respondents $(51.8 \%)$ behaved poorly on the use of personal protective equipment (PPE) at Lube Oil Blending Plant PT. Pertamina Lubricants Production Unit Jakarta. According to Fransiska (2014) that poor behavior towards the use of personal protective equipment (PPE) is influenced by several factors, namely predisposing factors include knowledge of low personal protective equipment, negative attitudes to the use of personal protective equipment, low motivation to use personal protective equipment, reinforcing factors include poor supervision of the use of personal protective equipment (PPE) and enabling factors including the availability of personal protective equipment.

Based on the description that has been explained that any worker who behaves does not use or does not use personal protective equipment (PPE), even though personal protective equipment (PPE) is the last risk control effort to minimize or reduce severity in the event of work-related illnesses or workplace accidents. Filling lithos process is the process of entering lubricants that have been produced from the blending process is filled into a container or packaging. in this process there are many worker activities. The risks in this activity or process, namely hearing loss, respiratory problems, hot temperatures, the risk of radiation, hand blisters or injuries, risky forklift mobilization causes workers to get hit, slip or fall, fall from heights, and risk falling or overload.

Based on the observation of the use of personal protective equipment (PPE) on the activity or process of lithos filling that most workers behave not using PPE in accordance with potential hazards or risks that exist. Therefore workers may behave unsafe behavior can be caused by many factors that influence it. Therefore, it is necessary to do research on factors that influence behavior by using Green theory, namely predisposing factors, enabling factors 
and reinforcing factors on the behavior of PPE use in PT Pertamina Lubricants Production Unit Gresik.

\section{METHODS}

This study was an observational type because only observes and does not carry out any treatment or intervention. This study was analytical research that analyzes the relationship between independent variables and dependent variables. The design of this study uses a cross sectional design that observes the independent variables and dependent variables at a certain time.

The location of this study was carried out in the lithos filling process of PT. Pertamina Lubricants Production Unit Gresik, Harun Tohir 77 street, Pulopancikan Village, Gresik, East Java. The time of this study was conducted from March to September 2018. Data collection was conducted in September 2018 at PT. Pertamina Lubricants Production Unit Gresik.

The population in this study were 68 workers. The sample size used in this study was 41 respondents. The method of sampling in this study was a probability sampling technique that simple random sampling. The simple random sampling technique in this study was carried out by lottery.

The dependent variable in this study was the behavior of use PPE and the independent variables in this study include age, knowledge, availability of PPE and regulations about PPE.

The way to collect primary data in study was interviews using questionnaires and observations using the observation sheet checklist. Secondary data in this study obtained from the company is a profile and data about PT. Pertamina Lubricants Production Unit Gresik and regarding personal protective equipment (PPE). Analysis data in this study was descriptive in narrative form and with statistical analysis use spearman's rho.

\section{RESULT}

\section{Characteristics of Respondents}

The characteristics of the respondents in this study were age. The youngest age in this study was 18 years old and the oldest was 54 years old. Most of the respondents have ages 18-40 years as many as 29 respondents $(70.7 \%)$ and ages $41-60$ years as many as 12 respondents $(29.3 \%)$.

This result shows respondents in the age group 18-40 years in the lithos filling process PT.
Table 1. Cross Tabulation Age with Behavior of Use PPE PT. Pertamina Lubricants Production Unit Gresik in 2018

\begin{tabular}{|c|c|c|c|c|c|c|}
\hline \multirow{3}{*}{$\begin{array}{c}\text { Age } \\
\text { (year) }\end{array}$} & \multicolumn{4}{|c|}{ Behavior of Using PPE } & & \\
\hline & \multicolumn{2}{|c|}{$\begin{array}{c}\text { Less } \\
\text { Obedient }\end{array}$} & \multicolumn{2}{|c|}{$\begin{array}{c}\text { Not } \\
\text { Obedient }\end{array}$} & \multicolumn{2}{|c|}{ Total } \\
\hline & n & $\%$ & $\mathbf{n}$ & $\%$ & $\mathbf{N}$ & $\%$ \\
\hline $18-40$ & 0 & 0 & 29 & 70.7 & 29 & 100 \\
\hline $41-60$ & 3 & 7.3 & 9 & 22 & 12 & 100 \\
\hline Sig (p value) & \multicolumn{6}{|c|}{0.004} \\
\hline $\begin{array}{l}\text { Correlation } \\
\text { Coefficient (r } \\
\text { value) }\end{array}$ & \multicolumn{6}{|c|}{-0.437} \\
\hline $\begin{array}{c}\text { Type of } \\
\text { correlation }\end{array}$ & \multicolumn{6}{|c|}{ Moderate } \\
\hline
\end{tabular}

Information: $\alpha=0.05$

Pertamina Lubricants Production Unit Gresik needs to be given training in the use of PPE, socialization of obedient PPE regulations, assistance with claims and ratios, and more optimal supervision. It can increase knowledge and extension of PPE and can also be used to build networks. Based on table 1 that the results of spearmans rho show the value of sig = $0.004<(\alpha=0.05)$, the age variable is related to the behavior of use PPE.

\section{Knowledge}

Knowledge of respondents in this study was that most respondents had good knowledge as many as 33 respondents $(80.5 \%)$ and respondents with sufficient knowledge as many as 8 respondents $(19.5 \%)$.

Based on Table 2 that the results of spearmans rho show the sig value $=0.388>(\alpha=0.05)$, the knowledge variable has no relation to the behavior of using PPE. Most workers do not obey using apd and knowledge factors do not have a relationship with the behavior of use apd can occur because there is an apd whose type is not in accordance with potential hazards, the level of knowledge of respondents who have the first level of knowledge, also caused by each individual has the ability different about K3 especially regarding PPE, there has not been any socialization of additional PPE in accordance with the potential hazards that must be used by workers, socialization of the Individual Work Procedure for PPE, HIRA socialization, and training about PPE is not routine.

Based on the results of the questionnaire in the aspect of knowledge that the respondents with moderate knowledge do not know the benefits of 
Table 2. Cross Tabulation of Knowledge with Behavior of the Use of PPE PT. Pertamina Lubricants Production Unit Gresik in 2018

\begin{tabular}{|c|c|c|c|c|c|c|}
\hline \multirow{3}{*}{ Knowledge } & \multicolumn{4}{|c|}{ Behavior of Using PPE } & \multirow{2}{*}{\multicolumn{2}{|c|}{ Total }} \\
\hline & \multicolumn{2}{|c|}{$\begin{array}{c}\text { Less } \\
\text { Obedient }\end{array}$} & \multicolumn{2}{|c|}{$\begin{array}{c}\text { Not } \\
\text { Obedient }\end{array}$} & & \\
\hline & n & $\%$ & $\mathbf{n}$ & $\%$ & $\mathbf{N}$ & $\%$ \\
\hline Good & 3 & 7.3 & 30 & 73.2 & 33 & 100 \\
\hline Enough & 0 & 0 & 8 & 19.5 & 8 & 100 \\
\hline Sig (p value) & \multicolumn{6}{|c|}{0.388} \\
\hline $\begin{array}{l}\text { Correlation } \\
\text { Coefficient (r } \\
\text { value) }\end{array}$ & \multicolumn{6}{|c|}{0.138} \\
\hline $\begin{array}{c}\text { Type of } \\
\text { correlation }\end{array}$ & \multicolumn{6}{|c|}{ Very Low } \\
\hline
\end{tabular}

using PPE and potential hazards that exist in the work area lithos filling process, do not know the consequences or disadvantages of not using PPE, and know when and where PPE must be used by workers.

\section{Motivation}

Motivation of respondents in this study was mostly 24 respondents $(58.5 \%)$ and respondents with moderate motivation as many as 17 respondents (41.5\%).

Based on Table 3 that the results of spearmans rho show the sig value $=0.388>(\alpha=0.05)$, the motivation variable has no relation to the behavior of using PPE. Most workers do not obey using PPE and motivation factors do not have a relationship with the behavior of use apd can occur because there is an apd whose type is not in accordance with potential hazards, the level of knowledge of respondents who have the first level of knowledge, also caused by each individual has the ability different about K3 especially regarding PPE, there has not been any socialization of additional PPE in accordance with the potential hazards that must be used by workers, socialization of the Individual Work Procedure for PPE, HIRA, and training about PPE is not routine.

Based on the results of the questionnaire that the motivation of respondents with motivation who use enough PPE so that they are not reprimanded or not sanctioned, using PPE is not due to their own needs or desires and using PPE is not to work safely and healthily.
Table 3. Cross Tabulation of Motivation with the Behavior of Use PPE PT. Pertamina Lubricants Production Unit Gresik in 2018

\begin{tabular}{|c|c|c|c|c|c|c|}
\hline \multirow{3}{*}{ Motivation } & \multicolumn{4}{|c|}{ Behavior of Using PPE } & \multirow{2}{*}{\multicolumn{2}{|c|}{ Total }} \\
\hline & \multicolumn{2}{|c|}{$\begin{array}{c}\text { Less } \\
\text { Obedient }\end{array}$} & \multicolumn{2}{|c|}{$\begin{array}{c}\text { Not } \\
\text { Obedient }\end{array}$} & & \\
\hline & $\mathbf{n}$ & $\%$ & $\mathbf{n}$ & $\%$ & $\mathbf{N}$ & $\%$ \\
\hline High & 3 & 7.3 & 21 & 51.2 & 24 & 100 \\
\hline Moderate & 0 & 0 & 17 & 41.5 & 17 & 100 \\
\hline Sig (p value) & \multicolumn{6}{|c|}{0.137} \\
\hline $\begin{array}{c}\text { Correlation } \\
\text { Coefficient } \\
\text { (r value) }\end{array}$ & \multicolumn{6}{|c|}{0.236} \\
\hline $\begin{array}{l}\text { Type of } \\
\text { correlation }\end{array}$ & \multicolumn{6}{|c|}{ Low } \\
\hline
\end{tabular}

\section{Availability of PPE}

Availability of PPE in this study based on filling out questionnaires according to all respondents as many as 41 respondents $(100 \%)$ stated that the availability of PPE in the lithos filling process is good.

Based on the questionnaire all respondents stated that availability is good so that the data is homogeneous, so correlation or relationship cannot be tested and it can be stated that there is no relationship between the availability of PPE and the behavior of using PPE.

PPE available in the process of lithos filling is additional PPE that is in accordance with the potential danger or risk of ear protectors, masks, gloves and glasses. Based on interviews with the HSSE and the foreman in the lithos filling process that PPE is available both on the HSSE and is available on the foreman to be stored and if requested or needed by workers will be given to workers.

\section{Regulation on PPE}

The regulation on PPE in this study was based on questionnaire that most respondents stated that the regulation on PPE was good as many as 38 respondents $(92.7 \%)$ and respondents stated that the regulation on PPE was less than 3 respondents $(7.3 \%)$.

Based on table 4 that the results of spearmans rho show sig $=0.624>(\alpha=0.05)$, the regulation variable about PPE has no correlation to the behavior 
of use PPE. Most workers do not obey using apd and regulation on PPE factors do not have a relationship with the behavior of use apd can occur because there is an apd whose type is not in accordance with potential hazards, the level of knowledge of respondents who have the first level of knowledge, also caused by each individual has the ability different about K3 especially regarding PPE, there has not been any socialization of additional PPE in accordance with the potential hazards that must be used by workers, socialization of the Individual Work Procedure for PPE, HIRA and training about PPE is not routine.

Based on the results of the questionnaire there were respondents who stated the rules of PPE in oral form, the absence of socialization regarding PPE regulations, the absence of regulations requiring workers to replace PPE if damaged.

\section{Behavior of Use PPE}

Based on observations using the observation sheet on the behavior of using PPE that most respondents behaved disobediently using PPE as many as 38 respondents $(92.7 \%)$ and respondents who behaved less obediently using PPE as many as 3 respondents $(7.3 \%)$. Most workers do not obey using PPE can occur because there is an apd whose type is not in accordance with potential hazards, the level of knowledge of respondents who have the first level of knowledge, also caused by each individual has the ability different about K3 especially regarding PPE, there has not been any socialization of additional PPE in accordance with the potential hazards that must be used by workers, socialization

Table 4. Cross Tabulation Regulations About PPE with Behavior Use PPE PT. Pertamina Lubricants Production Unit Gresik in 2018

\begin{tabular}{|c|c|c|c|c|c|c|}
\hline \multirow{3}{*}{$\begin{array}{l}\text { Regulations } \\
\text { About PPE }\end{array}$} & \multicolumn{4}{|c|}{ Behavior of Using PPE } & & \\
\hline & \multicolumn{2}{|c|}{$\begin{array}{c}\text { Less } \\
\text { Obedient }\end{array}$} & \multicolumn{2}{|c|}{$\begin{array}{c}\text { Not } \\
\text { Obedient }\end{array}$} & \multicolumn{2}{|c|}{ Total } \\
\hline & n & $\%$ & $\mathbf{n}$ & $\%$ & $\mathbf{N}$ & $\%$ \\
\hline Good & 3 & 7.3 & 35 & 85.4 & 38 & 100 \\
\hline Less & 0 & 0 & 3 & 7.3 & 3 & 100 \\
\hline Sig (p value) & \multicolumn{6}{|c|}{0.624} \\
\hline $\begin{array}{l}\text { Correlation } \\
\text { Coefficient ( } \mathrm{r} \\
\text { value) }\end{array}$ & \multicolumn{6}{|c|}{0.079} \\
\hline $\begin{array}{c}\text { Type of } \\
\text { correlation }\end{array}$ & \multicolumn{6}{|c|}{ Very Low } \\
\hline
\end{tabular}

Information: $\alpha=0.05$ of the Individual Work Procedure for PPE, HIRA socialization, and training about PPE is not routine.

None of the respondents in this study were obedient to using PPE in accordance with the potential hazards and risks required by HSSE. Standard PPE that must be used in the process of lithos filling is shoes and helmets, while additional PPE according to HSSE must be used are ear protectors, masks and gloves according to the potential danger and risk in the lithos filling process. This is very concern because in the lithos filling process there are types of physical, chemical, mechanical and transportation hazards which are at risk of causing work accidents and occupational diseases. Respondents who were less obedient were 3 respondents based on observations who used each of the 1 additional PPE required by the HSSE use masks, ear plugs and gloves.

Based on observations and interviews on respondents using additional PPE stated that using ear plug because they feel exposed to noise and feel pain in the ear while doing work, use a mask because they feel shortness of breath exposed to odors or emission and lubricating oil, and use gloves to avoid oil lubricant when doing work on the lithos filling process.

Based on observations and interviews with some respondents who did not use additional PPE stated that they did not use gloves, ear protectors, masks. Do not use ear protectors because they cause it is not easy to hear communication from other workers because difficult to communicate because the working environment conditions are noisy so that if you use ear plugs or communication masks between workers will be disturbed, while not using gloves because it will cause gloves to be easily exposed to oil or lubricants so that the hands become uncomfortable, and do not use masks because environment condition are noisy so that they feel disturbing communication between workers and workers feels hot if you use a mask to do work because the work climate conditions are processed hot lithos filling.

\section{DISCUSSION}

\section{Correlation between Age and Behavior of Using PPE}

According to Suryabudhi (2003) that a person who lives a normal life can be assumed that the longer the life, the more experience, the more knowledge, the more profound expertise and wisdom 
the better in making decisions on actions or behavior. According to Notoatmodjo (2014), the more the age, the level of maturity and strength of a person will be more mature in thinking and working.

This study shows that age has a relationship with the behavior of using PPE. The relationship between age and the behavior of the use of PPE is moderate and the direction of the relationship is negative or opposite, meaning that the older the age, the more obedient behavior he behaves using PPE. This is evident in the respondents aged 41-60 years, the older the respondents, the more they behave obedient use PPE.

The results of this study are in accordance with the results of a study by Faniah (2016) which states that there is a relationship between age and adherence to wearing or using PPE. This is supported by the opinion of Suryabudhi (2003) that a person who lives a normal life can be assumed that the longer life, the more experience, knowledge becomes wider, expertise becomes deeper and wisdom becomes better in making decisions on actions or behavior.

The older the age should be more obedient behavior using PPE, the reality in the field there are several things that affect the obedient behavior of using PPE can be caused by conditions in the field that there are differences in standard PPE that must be used by workers in the lithos filling process between standards according to production and HSSE irregular training in PPE, lack of socialization regarding PPE, absence of sanctions and rewards, and based on interviews with worker representatives that workers do not use additional PPE because they feel uncomfortable and feel disturbed while doing work.

\section{Correlation between Knowledge and Behavior Using PPE}

Knowledge is one aspect or factor in predisposing factors that affect a person's behavior. According to Notoatmodjo (2014) that knowledge is the fundamental domain of each person to act (overt behavior). According to Rengganis (2012) that the higher the knowledge, the higher a person will take actions related to that knowledge. According to Notoatmodjo (2007) that a person's behavior is based on knowledge he knows, the more knowledge a person has, the better his behavior than someone with little knowledge.

This study shows that knowledge was not correlated to the behavior of using PPE. Factors that cause knowledge have nothing to do with the obedient behavior of the use of PPE is for workers with high and moderate knowledge, there are still workers who do not understand or understand the benefits of PPE, when and where PPE is used, danger or risk in the workplace, and also respondents with high knowledge has the first level of knowledge that is know that is knowledge by knowing or recalcating existing memories after observing something.

The results of this study are in line with the results of the research of Fransiska (2014) which states that there is no relationship between knowledge and the use of personal protective equipment (PPE) at PT. Pertamina Lubricants Production Unit Jakarta.

High knowledge is not always in line or does not guarantee that workers will behave obediently using PPE, besides that also respondents in all categories of knowledge no one obediently uses PPE on respondents or workers in the lithos filling process PT. Pertamina Lubricants Production Unit Gresik can be attributed to the level of knowledge of respondents who have a level of knowledge at the first level, because every individual has the ability to capture information about K3 especially regarding different PPE, no additional PPE socialization must be used by workers, socialization of Tata Individual PPE work, HIRA socialization, and training on APD is not routine.

\section{Correlation between Motivation and Behavior Using PPE}

Motivation was one aspect or factor in predisposing factors that affect a person's behavior. According to Astuti (2001) states that one of the most important things to consider in individuals to behave is motivation. Motivation that exists in a person will affect someone whether to do each task properly or vice versa, whether he behaves safely or not.

This study shows that was not correlated to the behavior of using PPE. Factors that cause motivation are not related to the behavior of obedient use of PPE is to workers with high motivation and motivation while there are still respondents who claim to use PPE so that they are not reprimanded or not sanctioned. has almost the same number or frequency. This may be due to regulations or the supervision of PPE. The results of this study are in line with the results of the research by Noviandry (2013) which states that there is no relationship 
between motivation and worker behavior in the use of personal protective equipment (PPE).

The high motivation is not always in line or does not guarantee that workers will behave obediently using PPE, besides that there are no respondents in all categories of motivation who behave obediently using PPE can be caused by individual factors in the respondent's motivation, and can also be caused optimal socialization of additional PPE that must be used by workers, socialization of the Individual Work Procedure for PPE, HIRA socialization, training has not been routinely conducted on PPE, and there has been no firm sanctions and awards.

\section{Correlation between Availability of PPE and the Behavior of Using PPE}

Availability of PPE is a factor that allows or facilitates the formation of a person's behavior. A person's behavior is not only influenced by the availability of facilities and infrastructures, namely the availability of PPE, but also due to predatory factors and driving factors. PPE must be provided by the company to workers at work, free of charge, and every worker entering the workplace must use PPE in accordance with potential hazards and risks.

Based on the results of questionnaire filling that all respondents stated that the availability of PPE in the lithos filling process is good, the data is homogeneous so that it can be stated that there is no relationship between the availability of PPE and the behavior of using PPE. This result could be caused by other factors, namely respondents who thought using PPE spent time and hampered work, not optimal socialization of additional PPE that must be used by workers, socialization of Individual PPE Work Procedure, HIRA socialization, training on PPE was not routine.

The results of this study are in line with the results of the Apriluana, Khairiyati and Setyaningrum (2016) which states that there is no relationship between the availability of PPE and the behavior of using PPE

Personal protective equipment (PPE) in the lithos filling process has been provided by the company. This is in accordance with Minister of Manpower and Transmigration (2010) concerning Personal Protective Equipment in article 2 paragraph 1.

PPE in the lithos filling process is provided by the company free of charge to workers. This is in accordance with Minister of Manpower and Transmigration Regulation Number 08 of 2010 concerning Personal Protective Equipment in article 2 paragraph 3.

\section{Correlation between Regulation about APD and Behavior of Using PPE}

Supervision is a factor that drives the formation of a person's behavior. In addition to the driving factors, that a person's behavior is influenced by predisposing factors and enabling factors. Regulations that have a large role in determining safe behavior that is acceptable and unacceptable (Sialagan, 2008). According to Geller (2001), regulations are written documents that document standards, norms and policies for expected behavior.

This study, it shows that the rules regarding PPE have no relation to the behavior of using PPE. Factors that cause the rule there is no relationship with the obedient behavior of the use of PPE because of individual factors of respondents, who argue that using PPE takes up time and hinders work and makes respondents or workers uncomfortable in working.

The results of this study are in line with the results of Fransiska (2014) study which states that there is no relationship between PPE regulations and the use of personal protective equipment (PPE) at PT. Pertamina Lubricants Production Unit Jakarta.

Regulations regarding good PPE are not always in line or do not guarantee that workers will behave obediently using PPE, also that regulations on good PPE are not always in line or do not guarantee that workers will behave in an obedient manner using PPE, as well as responses stating good regulations and lacking regulations who behave obediently using PPE in the lithos filling process PT. Pertamina Lubricants Production Unit Gresik can be caused other than due to individual factors of respondents or workers also due to the lack of optimal socialization of PPE that must be used by workers, socialization of Individual PPE Work Procedures, HIRA socialization, training on PPE is not yet routine, regulations that are not firm and not yet there are strict sanctions and awards.

\section{CONCLUSION}

The behavior of using PPE workers in the lithos filling process PT. Pertamina Lubricants The Production Unit of Gresik, which is mostly 38 respondents in the process of lithos filling behaves 
in a non-compliant manner using PPE and only 3 respondents who behave less adhere to using PPE.

Age factor has a relationship with the behavior of using PPE workers in the lithos filling process PT. Pertamina Lubricants Production Unit Gresik. the strong relationship between age and the behavior of using PPE is a strong moderate relationship and the direction of a negative or opposite relationship. While the knowledge, motivation, availability of PPE and regulations about PPE have no relation with behavior of using PPE in workers in the lithos filling process PT. Pertamina Lubricants Production Unit Gresik.

\section{ACKNOWLEDGEMENT}

I express my deepest gratitude and appreciation to Dr. Ir. Y. Denny Ardyanto W, M.Sc. as a supervisor who has given instructions, corrections and suggestions to the realization of this study. Thank you to the Airlangga University Faculty of Public Health for helping the journal's sustainability. Thank you to $\mathrm{Mr} / \mathrm{Ms}$, for their willingness to review the journal manuscript and all parties for contributing in this study.

\section{REFERENCES}

Apriluana, G., Khairiyati, L. and Setyaningrum, R. (2016) 'Hubungan antara Usia, Jenis Kelamin, Lama Kerja, Pengetahuan, Sikap dan Ketersiediaan Alat Pelindung Diri dengan Penggunaan APD pada Tenaga Kesehatan', Jurnal Publikasi Kesehatan Masyarakat Indonesia, 3(3), pp. 82-87.

Astuti, Y. (2001) Faktor-Faktor yang Berhubungan Dengan Motivasi Perawat Rumah Sakit Jiwa (RSJ) untuk Mengikuti Pendidikan: Studi Kasus di Tiga RSJ di Jawa Barat. Undergraduate Thesis. Depok: Faculty of Public Health, Universitas Indonesia.

Faniah,A. M. (2016) Faktor-Faktor yang Berhubungan dengan Kepatuhan Penggunaan APD Earplug dan Sarung Tangan pada Pekerja Unit Perbaikan di PT. KAI DAOP VI Yogyakarta Dipo Solo Balapan. Undergraduate Thesis. Surakarta: Faculty of Health Sciences, Universitas Muhammadiyah Surakarta.

Fransiska, A. (2014) Analisis Penggunaan Alat Pelindung Diri (APD) pada 2014 PT. Area
Kerja Unit Produksi Pelumas Pertamina Lube Oil Blending Plant (LOBP) pada tahun 2014. Undergraduate Thesis. Depok: Faculty of Public Health, Universitas Indonesia.

Geller, E. S. (2001) The Psychology of Safety Handbook. Boca Raton: Lewis Publishers.

International Labour Organization (2017) Occupational Health and Safety and Youth in Indonesia. Jakarta: International Labour Organization.

Minister of Manpower and Transmigration (2010) Regulation Number PER-08/MEN/VII/2010 concerning Personal Protective Equipment, Ministry of Manpower and Transmigration. Jakarta.

Notoatmodjo, S. (2007) Promosi Kesehatan dan Ilmu Perilaku. Jakarta: Rineka Cipta.

Notoatmodjo, S. (2014) Promosi Kesehatan dan Perilaku Kesehatan. Jakarta: Rineka Cipta.

Noviandry, I. (2013) Faktor-Faktor yang Berhubungan dengan Perilaku Pekerja dalam Penggunaan Alat Pelindung Diri (APD) di Industri Pengelasan Informal di Kecamatan Gondrong, Kecamatan Cipondoh, Kota Tangerang 2013. Undergraduate Thesis. Jakarta: Faculty of Medicine and Public Health, Universitas Islam Negeri Syarif Hidayatullah.

Ramli, S. (2010) Sistem Manajemen Keselamatan dan Kesehatan Kerja OHSAS 18001. Jakarta: Dian Rakyat.

Rengganis, F. (2012) Faktor-Faktor yang Mempengaruhi Perilaku Pekerja Percetakan terhadap Penggunaan Alat Pelindung Diri (APD) di Bagian Produksi PT. Antar Surya Jaya Surabaya. Undergraduate Thesis. Surabaya: Faculty of Public Health, Universitas Airlangga.

Saputro, V. A. (2015) Hubungan antara Pengetahuan dan Sikap dengan Penggunaan Alat Pelindung Diri (APD) pada Pekerja di Unit Produksi Pengecoran Logam. Undergraduate Thesis. Surakarta: Faculty of Health Sciences, Universitas Muhammadiyah Surakarta.

Sialagan, R. T. (2008) Analisis Faktor-Faktor yang Berkontribusi pada Perilaku Aman di PT EGS Indonesia Tahun 2008. Depok: Faculty of Public Health, Universitas Indonesia.

Suryabudhi, M. (2003) Cara Merawat Bayi dan AnakAnak. Bandung: Alfabeta. 